\title{
Taxonomic and Medicinal Study of Papilionaceae of District Upper Dir, Khyber Pakhtunkhwa, Pakistan
}

\author{
Ali Hazrat ${ }^{1 *}$, Mohammad Nisar ${ }^{1}$, Khan Sher $^{2}$, Jehandar Shah $^{2}$, Tour Jan ${ }^{1}$ and Abid Ullah ${ }^{1}$
}

${ }^{1}$ Department of Botany, University of Malakand at Chakdara, Dir Lower, Khyber Pakbtunkhwa, Pakistan; ${ }^{2}$ Department of Botany SBBU, Sheringal, Dir Upper, Khyber Pakbtunkhwa, Pakistan.

\begin{abstract}
Twenty seven plant species of the Papilionaceae were collected from Dir Upper, with elevation ranges from 1200-4000 meters during 2015-2017. They were taxonomically determined with the help of key characters, the uses of these native plants were recorded such type of study was concluded for the first time in the selected area of Dir (Upper). In view of the fact that these plant species are scarcely distributed, hence struggle should be made to protect them. The key objective of the present study was to file the taxonomic knowledge and the local and medicinal uses of the root juice of Desmodium elegans DC, combined with the bark juice of Baubinia malabarica for the treatment of cholera, branches of the Indigofera heterantha Wal. ex Brands vari; gerardiana used in basket making, twig bridges making, soil cover for preventing erosion. Similarly, Astragalus genus used as a fodder, fuel wood, miswak, fatigue, tooth ache, Crotalaria juncea forage for goats and cattle and also toxic alkaloids, particularly in the seeds and pods, Lathyrus cicera is used as a green manure, soil cover for preventing erosion and in breeding program for the plant species, Medicago minima is rich source of vitamins $\mathrm{A}, \mathrm{C}$, and $\mathrm{E}$, green manure and fixes atmospheric nitrogen, Robinia pseudo-acacia is astringent, diuretic, emetic, emollient, laxative, poison, purgative, sedative, tonic, emetic and for toothache, Sophora mollis is seed destroying verm, wood used as fuel, Trifolium repens antirheumatic tonic and ointment, Trigonella emodi flowers and leaves are dried and powdered. One spoon of powder is taken twice a day for one week to cure jaundice, Vicia faba can be eaten before it is fully ripened in the same way as broad beans, fully ripened seed requires overnight soaking to soften it before cooking. All the species of the selected family are reported for the first time and studied for medicinal purposes.

Received | June 17, 2019; Accepted | August 21,2020; Published | September 08, 2020

*Correspondence | Ali Hazrat, Department of Botany University of Malakand at Chakdara, Dir Lower, Khyber Pakhtunkhwa, Pakistan; Email: aliuom@gmail.com

Citation | Hazrat, A., M. Nisar, K. Sher, J. Shah, T. Jan and A. Ullah. 2020. Taxonomic and medicinal study of papilionaceae of District Upper Dir, Khyber Pakhtunkhwa, Pakistan. Sarhad Journal of Agriculture, 36(3): 974-978.

DOI | http://dx.doi.org/10.17582/journal.sja/2020/36.3.974.978

Keywords | Papilionaceae, Taxonomy, Dir Upper, Key to species and Genera and Medicinal/ Local uses
\end{abstract}

\section{Introduction}

$\mathrm{T}$ he investigation was completed in Dir upper. The zone is situated between $34^{\circ} 10^{\prime} \mathrm{N}$, latitude and $72 \circ 20^{\prime} \mathrm{E}$, longitudes in a subtropical dry temperate bit of Hindu Kush range. Region Dir (Upper) is among the 26 districts of KP region and spreads a territory of $3699 \mathrm{Km}^{2}$.Kohistan valley begins with its portal called "Khawgo Ooba" and reached out to Kumrat around $120 \mathrm{~km}$. According to the forest division the area of Dir Kohistan is 645 square miles. Out of this a zone of 1, 40351 sections of land were secured by coniferous/pine forest (Hazrat et al., 2010; Hazrat, 2020). The relative humidity is very high consistently, while most extreme humidity has been recorded in the month of Jan; to February. The zone gives natural 
habitat to the development of an expansive number of plants. It has a rich diversity of plant resources (Bhatti et al., 2010).

Papilionaceae usually known as of the pea family is comprised of herbs and shrubs of about 375 genera and 500 species found extremely varied soil and climatic conditions. The family is cosmopolitan and rank second among the dicot families including other two sub families of Leguminosae (Philcox, 1990) carry out a preliminary study of the flora of Hindukush Range and published a checklist of 144 medicinal plants from the selected region. Furthermore, the floristic and Ethnobotanical study from some parts of this area (Bhati et al., 2010). Since, Papilionaceae on this name is poorly known and not so far published from this area; an effort has been made to report the members of the Papilionaceae from the study area. The present paper is the only source of systematic account of the Papilionaceae from the selected area.

\section{Materials and Methods}

Field trips were arranged in the whole areas of Dir upper in different seasons of 2015-2017. The area information was collected with respect to the plant species from locals through individual meetings questionnaires and dialogs and so on. The indigenous knowledge incorporates the local name of the plant sample, blooming and fruiting seasons, flower color, lifetime and so forth. The identification of the scientific names of the plants was made with the assistance of authentic literature of various authors (Ali and Nasir, 1989-1992; Ali and Qaiser, 19932018; Nasir and Ali, 1980-1989; Jafri, 1966; Philcox, 1990; Hazrat et al., 2020). The plant samples have been housed in the herbarium of Botany Department; SBB University, Wari Campus and the University of Malakand Chakdara for future research exercises of BS to Ph.D. level.

\section{Results and Discussion}

Floristic survey of the district was conducted with regular intervals in summer and spring in the years of 2015-2017 for collection of plant samples. Twenty seven plant species distributed across eleven genera of the selected family have been identified. Their serial number (S.N), Voucher number (V.N), Botanical name, Vernacular name (Vern; N) Research area and Local/Medicinal uses are given Table 1.
Key to the genera

1. Shrub, tree---2

+ Herbs---5

2. Stamens free---Sophora

+ Stamens not free ----3

3. Leaf trifoliolate---Desmodium

+ Leaf not trifoliolate ----4

4. Tree with stipular spines----Rubinia

+ Shrub without stipular spines----Indigofera

5. Leaves with tendrils-----6

+ Leaves without tendrils -----7

6. Staminal tube with truncate mouth----Lathyrus

+ Staminal tube with oblique mouth-----Vicia

7. Leaf simple----Crotalaria

+ Leaf compound-----8

8. Fruit, spirally, coiled----Medicago

+ Fruit otherwise----9

9. Leaf trifoliate ------10

+ Leaf pinnate-----Astragalus

10. Fruit 1-2 seeded----- Trifolium

+ Fruit many seeded----Trigonella

Genus: Desmodium DC. 1825.

Key to the species

1. Fruit stipe and bent at right angles to it's stalk----Desmodium podocarpum

+ Fruit usually sessile, not bent at right angles to its stalk-----Desmodium elegans

Genus: Indigofera L., 1753.

\section{Key to the variety}

1. Fruit 1-1.6 cm long---Indigofera heterantha var. beterantha

+ Fruit 2-5.0 cm long ----Indigofera heterantha var. gerardiana.

\section{Genus: Lathyrus L., 1753.}

Key to the species

1. Leaflets, absent-----Lathyrus aphaca

+ Leaflets, present-----2

2. Leaflets -------Lathyrus humilis

+ Leaflets 2-------3

3. Inflorescence 5-12 flowered----Lathyrus pratensis

+ Inflorescence one flowered-----4

4. Fruit upper suture broadly wing; 3-5 seeded---Lathyrus satious

+ Fruit upper suture flattened, with two narrow lateral keels; 2-6 seeded----Lathyrus cicera 
Table 1: Check list of Papilionaceae plant species collected from the selected research area.

\section{S.N V.N Botanical name}

415 Astragalus pyrrhotrichus Boiss.

\section{Vern; $\mathbf{N}$}

Mamol

2434 Astragalus anisacanthus Boiss. Mamol

3

695 Astragalus graveolens Buch.Ham. ex Bth.

4425 Astragalus psilocentros Fisch. Mamol

5395 Crotalaria juncea L.

Nil

6

692 Desmodium elegans DC.

Chamkat

\section{Research area}

Sheringal, Dogdara, Sunderae

Kumrat, Dogdara

Sheringal, Sunderae, Lamutai, Janus candio

\section{Local/Medicinal uses}

Diarrhea, fatigue, infections, heart disease, hepatitis and therapy for cancer

Fodder and fuel wood

Miswak, fodder and fuel wood

Kumrat, Sunderae, Lamutai, Flue and tooth ache Janus candio

Sunderai , Dogdara, Sheringal

Thall, Dogdara, Sunderae

Roots are diuretic, carminative and tonic,
Forage for goats and cattle and also toxic alkaloids,particularly in the seeds and pods also used in the treatment of bilious complaints, juice of the root combine with the bark juice of Baubinia malabarica, for the treatment of cholera

7443 Desmodium podocarpum DC. Chamra

715 Indigofera heterantha Wal. ex Ghwaraja Brands vari;gerardiana (Wal. ex Bker) Ali

725 Indigofera heterantha Wal. Ex Ghwaraja Brands var; Heterantha

10414 Lathyrus cicera $\mathrm{L}$.

Wara Chilo Thall, shahoor

11862 Lathyrus humilis (Ser.) Fis- Juga cher ex Sprengel.

12842 Lathyrus aphaca L

13672 Lathyrus sativus $\mathrm{L}$.

14682 Lathyrus pratensis L.

GhataChilo Kumrat, Dogdara

Ziara Chilo Thall, Patiobanda

15

735 Medicago laciniata (L.) Mill. Shpeshtarae She Var laciniata

16745 Medicagolupulina L.

Shepesther

755 Medicago minima

(L.) Grufb. Kachspester

404 Medicago polymorpha L.

Nil

19

850 Robinia pseudo-acacia L.

Kikar

20

384 Sophora mollis (Royle) Baker Badaga ssp mollis

21364 Trifolium repens $\mathrm{L}$.

22931 Trifolium resupinatum $\mathrm{L}$.

Shaftal

23 921 Trigonella emodi Both.

Shaftalkach Shahoor

Nil

Sheringal

Shahoor, Dogdara, Sherin- Branches are used in basket making, making gal, Sunderae, Lamutai, Janus twig bridges and fuel

candio

Common

Shahoor, Dogdara

Whole plant used for reducing fever, malaria, coughs, bleeding wounds, treating dysentery, rheumatism, anti-inflammatory and antipyretic. Branches are used in basket making, making twig bridges and fuel

Used as a green manure, soil cover for preventing erosion and used in breeding program for the species.

Ripe seeds are said to be antibacterial and narcotic

For the treatment of toothache

Seed oil is powerful and dangerous cathartic Used to repel mice

Used in condiment for tea, or is mixed with boiled water and sugar to form a beverage

Sheringal, Dogdara, Sunder- Leaves are antibacterial ae, Lamutai

Rich source of vitamins $\mathrm{A}, \mathrm{C}$, and $\mathrm{E}$, green manure and fixes atmospheric nitrogen

Rich source of vitamins A, C, and E

Astringent, diuretic, emetic, emollient, laxative, Poison, purgative, sedative, tonic, emetic and for toothache

Shahoor, Dogdara, Lamutai, Seed destroying verm, wood hard used is fuel Janus candio

Sheringal, Dogdara

Antirheumatic tonic and ointment

Antirheumatic, detergent and tonic

Flowers and leaves are dried and prepare powder. One spoon of powder is taken twice a day for one week to cure jaundice

Antidiabetic, anti-inflammatory, antitumor, carminative, demulcent, emollient, expectorant and febrifuge, 


\begin{tabular}{|c|c|c|c|c|c|}
\hline 25 & 891 & Vicia faba L. & $\begin{array}{l}\text { Marghai } \\
\text { Khpa }\end{array}$ & $\begin{array}{l}\text { Sheringal, Dogdara, Sunder- } \\
\text { ae, Lamutai, Janus candio }\end{array}$ & $\begin{array}{l}\text { It can be eaten before it is fully ripe in the } \\
\text { same way as broad beans, fully ripe seed } \\
\text { requires overnight soaking to soften it before } \\
\text { cooking. }\end{array}$ \\
\hline 26 & 344 & Vicia monantha Retz. & Maregkpa & $\begin{array}{l}\text { Sheringal, Dogdara, Sun- } \\
\text { derae, }\end{array}$ & $\begin{array}{l}\text { The seed can be dried, ground into a powder } \\
\text { and mixed with cereal flour to make bread, } \\
\text { biscuits, cakes and rich source of protein. }\end{array}$ \\
\hline 2 & 354 & Vicia birsuta (L.) S.F.Grey & Mardikakh & $\begin{array}{l}\text { Shahoor, Dogdara, Sheringal, } \\
\text { Sunderae, Lamutai, Janus } \\
\text { candio }\end{array}$ & $\begin{array}{l}\text { The seeds, leaves, and stem can be cooked } \\
\text { and also be used as a cover crop to add } \\
\text { nitrogen to the soil, which can then be used } \\
\text { by other plants. }\end{array}$ \\
\hline
\end{tabular}

\section{species}

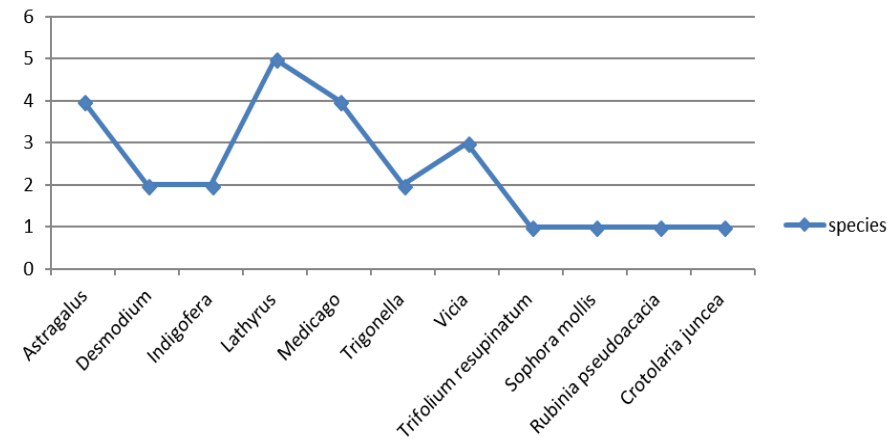

Figure 1: Number of species of each genus of the family.

Genus: Vicia L., 1753.

\section{Key to the species}

1. Leaf rachis terminating in a leaflet, bristle--------2

+ Leaf rachis terminating in a tendril-------- $V$. hirsuta

2 Herbs annual legumes50-100 × 20-30 mm: racem; rachis short to absent----------------------- $V$. faba + Herbs perenial legumes 20-50 × 5-8 mm: racem; rachis obvious ---- $V$. monantha

Genus: Medicago L., 1753.

\section{Key to the species}

1 Fruits, echinulate -----2

+ Fruits not echinulate----Medicago lupulina

2 The spine of the fruitsorientedeparallels to the exterior of the discs----Medicago polymorpha

+ The spine of the fruits oriented at rights angle to the exterior of the disc-----3

3. Leaflets cuneat;pubesscent on the lowers surface only, spine of the fruit inserted on the dorsals sutures-----Medicago laciniata

+ Leafletobovat; rarely oblanceolat; pubescent on both surface, spine of the fruits not inserted on the dorsals sutures-----Medicago minima

Genus: Astragalus L., 1753.
Key to the species

1. Fruiting calyx does not become inflate------------2 + Fruiting calyx become inflate-Astragalus anisacanthus 2. Leaf imparipinnately compound------------------3 + Leaf paripinnately compound-Astragalus psilocentros 3. Flowers sessile or subsessile, forming a compact head-----Astragalus graveolens+ Flowers pedicellate, not forming a compact head---Astragalus pyrrhotrichus

\section{Genus: Trifolium L.1753.}

\section{Key to the species}

1. Inflorescence a peduncled head; Leaflets 7-30 mm long-------------------------------T. resupenatum + Inflorescence a globose raceme; Leaflets $1-4 \mathrm{~cm}$ long ----------------------------------T. repens

Genus: Trigonella L., 1753.

\section{Key to the species}

1. Perennial herbs; legume linear-oblong-----T. emodi + Annual herbs; legume cylindrical or ovoid---T. foenum-graecum

\section{Conclusions and Recommendations}

These data showed the Papilionaceae species provide scientific basis to the local/medicinal uses. Further studies are required to find out the nature of chemical constituent and pharmacological effects of the species selected family.

\section{Novelty Statement}

All the plant species of the selected family are reported for the first time from the selected area and studied for Taxonomic and medicinal purposes. 
Author's Contribution

Ali Hazrat: Designed and performed the experiments

Mohammad Nisar: Wrote the manuscript.

Khan Sher: Proofread the manuscript.

Jehandar Shah: Identification of plants.

Tour Jan: Data analysis.

Abid Ullah: Reviewed the manuscript.

\section{Conflict of interest}

The authors have declared no conflict of interest.

\section{References}

Ali, S.I. and M. Qaiser. (Eds.). 1993-2018. Flora of Pakistan. No. 191-215. Islamabad, Karachi.

Ali, S.I. and Y.J. Nasir. (Eds.). 1989-1992. Flora of Pakistan. Nos. 191-204. Islamabad, Karachi.

Bhati, J., H. Sonah, T. Jhang, N.K. Singh and T.R. Sharma. 2010. Comparative analysis and comparative and functional genomics. https:// doi.org/10.1155/2010/520238

Hazrat, A., 2020. Floral diversity of rosaceae family in dir kohistan forest Khyber Pakhtunkhwa Province-Pakistan. Pak. J. Weed Sci. Res., 26(2): 157-165.

Hazrat, A., J. Shah, S. Ahmad, M. Nisar, A.K. Jan and Sikandar. 2010. Medicinal plants of Usherai Valley Dir, NWFP, Pakistan. Pak. J. Bot., 42(1): 31-34.

Hazrat, A., Z. Shah, K. Sher, Z. Ahmad, S. Bibi, G. Rahim, S. Zaman, Z. Fazal, M. Mukhtiar, T. Nowsheen, J. Zada and A. Khan. 2020. Floristic diversity and ecological characteristics of flora, Kharawo Talash, district Dir lower, Khyber Pakhtunkhwa, Pakistan. Res. Art. Biosci. Res., 17(1): 681-687. Open Access.

Jafri, S.M.H., 1966. The flora of Karachi. The book corporation, Pakistan.

Nasir, E. and S.I. Ali. (Eds.). 1980-1989. Flora of Pakistan. No. 132-190. Islamabad, Karachi.

Philcox, D., 1990. Scrophulariaceae, Flora of Zimbabwe. 8(2): 87-89. 